\title{
Overview and perspectives on the transcriptome of Paracoccidioides brasiliensis
}

Rosângela V. Andrade ${ }^{1}$, Silvana P. da Silva ${ }^{2}$, Fernando A. G. Torres ${ }^{1}$, Marcio José Poças-Fonseca' ${ }^{1}$ Ildinete Silva-Pereira' ${ }^{1}$, Andrea Q. Maranhão', Élida G. Campos ${ }^{1}$, Lídia Maria P. Moraes ${ }^{1}$, Rosália S. A. Jesuíno ${ }^{3}$, Maristela Pereira ${ }^{3}$, Célia M. A. Soares ${ }^{3}$, Maria Emília M. T. Walter', Maria José A. Carvalho ${ }^{1}$, Nalvo F. Almeida ${ }^{4}$, Marcelo M. Brígido ${ }^{1}$ and Maria Sueli S. Felipe ${ }^{1}$

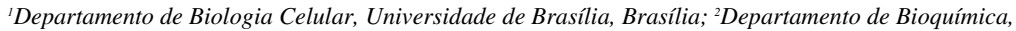
Universidade Estadual de Londrina, Londrina: ${ }^{3}$ Departamento de Bioquímica, Universidade Federal de Goiás, Universidade Estadual de Londrina, Londrina: ${ }^{3}$ Departamento de Bioquímica, Universidade Federal de Goiás,
Goiânia; ${ }^{4}$ Departamento de Computação e Estatística, Universidade Federal de Mato Grosso do Sul, Campo
Grande, Brazil

Summary Paracoccidioides brasiliensis is a dimorphic and thermo-regulated fungus which is the causative agent of paracoccidioidomycosis, an endemic disease widespread in Latin America that affects 10 million individuals. Pathogenicity is assumed to be a consequence of the dimorphic transition from mycelium to yeast cells during human infection. This review shows the results of the $P$. brasiliensis transcriptome project which generated 6,022 assembled groups from mycelium and yeast phases. Computer analysis using the tools of bioinformatics revealed several aspects from the transcriptome of this pathogen such as: general and differential metabolism in mycelium and yeast cells; cell cycle, DNA replication, repair and recombination; RNA biogenesis apparatus; translation and protein fate machineries; cell wall; hydrolytic enzymes; proteases; GPI-anchored proteins; molecular chaperones; insights into drug resistance and transporters; oxidative stress response and virulence. The present analysis has provided a more comprehensive view of some specific features considered relevant for the understanding of basic and applied knowledge of $P$. brasiliensis.

Key words Transcriptome, Expressed Sequence Tags, Dimorphic and thermo-regulated fungus, Paracoccidioides brasiliensis

\section{Panorama y perspectivas del transcriptoma de Paracoccidioides brasiliensis}

Resumen Paracoccidioides brasiliensis es un hongo de dimorfismo termorregulado que es el agente causal de la paracoccidioidomicosis, una enfermedad endémica muy extendida en América Latina que afecta a 10 millones de individuos. Se asume que la patogenicidad es una consecuencia de la transición dimorfa de micelio a levadura durante la infección humana. Esta revisión muestra los resultados del proyecto de transcriptoma de $P$. brasiliensis, que generó 6.022 grupos ensamblados de las fases miceliar y levaduriforme. El análisis por ordenador utilizando herramientas bioinformáticas reveló varios aspectos del transcriptoma de este patógeno, como el metabolismo general y diferencial en el micelio y las levaduras, el ciclo celular, la replicación, reparación y recombinación del ADN, el aparato para la biogénesis del ARN, las maquinarias de traslación y destino de las proteínas, la pared celular, las enzimas hidrolíticas, las proteasas, las proteínas con anclaje GPI, los chaperones moleculares, el entendimiento de la resistencia a fármacos y los transportadores, la respuesta al estrés oxidativo y la virulencia. Este análisis ha proporcionado una visión más amplia de algunos aspectos específicos considerados relevantes para entender el conocimiento básico y aplicado de $P$. brasiliensis.

Palabras clave Transcriptoma, Etiquetas de secuencia, Hongo dimorfo y termorregulado, Paracoccidioides brasiliensis 
Paracoccidioidomycosis (PCM) is the most important systemic mycosis in Brazil and widespread in Latin America with about 10 million individuals infected being $\sim 2 \%$ developing the disease [88]. Since $85 \%$ of PCM cases occur in Brazil, this disease represents a major health problem, being classified as the first cause of death among systemic mycoses, and the eighth, with respect to infectious and parasitic diseases [33,88]. PCM represents a serious public health challenge, with social and economical importance. Infected individuals comprise rural workers living where forests and agriculture abound [16] and immunocompromised patients [94] including individuals with AIDS. PCM is characterised by granulomatous inflammation, suppression of cellular immunity and high antibody titres $[40,90]$. The disease may develop as a benign and localized form to severe and disseminated [49] affecting the skin, lymph nodes and various internal organs, including the lungs and the central nervous system [89]. All patients from whom the fungus is isolated should be treated, and pulmonary fibrosis is still the major sequel despite the availability of new antifungal drugs for therapy.

The etiological agent of PCM is the fungus Paracoccidioides brasiliensis, an ascomycete closely related to other pathogenic fungi such as Blastomyces dermatitidis and Histoplasma capsulatum [7]. P. brasiliensis exists as mycelium in the soil environment and as yeast in the host. The unicellular hyphae and fungal propagules or conidia are uninucleate, while yeasts are multinucleate. Infection typically occurs by inhalation of dry airborne spores, fungal propagules or mycelium fragments, which settle in the airways following the thermally regulated transition to the parasitic yeast phase $[67,96]$. The yeast form has a well-established habitat as a parasite of animals, including humans, armadillos and penguins [6,25]. Many aspects of $P$. brasiliensis ecology remain unclear, especially those that concern its environmental niche $[68,88]$. The morphological switch from mycelium to yeast is the most important biological feature that enables $P$. brasiliensis to colonize, invade and survive in the warm-blooded host [96]; strains unable to differentiate into yeast do not cause disease [14]. In vitro, this process can be reversibly driven mainly by a temperature switch from $26{ }^{\circ} \mathrm{C}$ to $36{ }^{\circ} \mathrm{C}$. The morphogenetic changes are directly associated to the life cycle of this fungus; it undergoes molecular alterations during the morphogenetic switch from hypha to the yeast phase [36].

The degree of pathogenesis varies according with host features and infecting lineage virulence. The immune response of the hosts against $P$. brasiliensis depends on factors such as, sex, age, nutritional state and genetic inheritance. PCM can be restricted to respiratory tract or disseminated all over the organism, and so, being lethal [49]. Thus, the forms of PCM can be divided into two groups: PCM infection, which is generally self-limited and restricted to the site of contact with fungi fragments or to a single organ, affecting both sexes indistinctly; and PCM disease, which preferentially attacks males and can evolve benignly to a PCM infection or disseminate systemically imputing severe damage to the host.

The fungus-host interaction will depend mainly on the host immunological response and fungal virulence. Clinical and experimental data indicate that cell-mediated immune response is the main mechanism of defense against $P$. brasiliensis infection, whereas specific antibodies produced in large amounts do not confer protection $[11,24,47,60,66]$. Protective cell-mediated immune response in PCM is characterized by the production of cytokines (TNF- $\alpha$, IL-12 and IFN- $\gamma$ ) that are required for the activation of macrophages, the major defensive cell against $P$. brasiliensis $[5,27,102]$. In the absence of such cytokines, such as in susceptible hosts, macrophages serve as a protected environment in which fungus can undergo intracellular replication and disseminates from the lungs to other organs $[17,18,19,20,50,75]$ as suggested in histoplasmosis [113]. All patients from whom the fungus is isolated must be treated, and despite new antifungal drugs, pulmonary fibrosis is still the most frequent sequel. The outcome of infection depends on several factors, including host responses and the virulence of the infecting isolate. PCM treatment lasts up to five years and uses basically sulphonamides, azoles and amphotericin B, with successful rates [52].

Information on the genetic composition of $P$. brasiliensis is scarce. The nuclear genome size estimated by PFGE (Pulsed Field Gel Eletrophoresis) is around $30 \mathrm{Mb}$ and confocal fluorescence microscopy studies suggest that $P$. brasiliensis is haploid/diploid or even aneuploid [42]. The electrophoretic pattern revealed chromosomal polymorphism in the fungus, which presented 4-5 chromosomal DNA molecules according to the analyzed isolate, showing molecular sizes ranging from 2$10 \mathrm{Mb}[42,71]$. Based on the DNA sequencing of $\sim 50 \mathrm{~Kb}$ of a $P$. brasiliensis genome fragment, it is estimated that is a total of 7,500-9,000 genes [86].

Our group has been working for the last 10 years in order to identify the differentially expressed genes involved in the dimorphism of $P$. brasiliensis and also genes encoding proteins which are immunogenic in humans during infection. Several genes up-regulated in mycelium and yeast cells have been previously identified by DDRTPCR (Diferencial Display Reverse Transcriptase PCR), proteome analysis and immunoscreening of cDNA libraries from mycelium and yeast cells using patient's sera [1,8,34-37,43,46,58,73,82,92,93,109].

An important and efficient approach for the comparative study of various genomes is the sequencing of expressed sequence tags (ESTs) which reflects the expression profile of different tissues, cell types or developmental stages [84]. EST data is useful for the discovery of homologous genes, detection of polymorphism and alternative splicing of mRNAs; identification of vaccine candidate molecules, new drug targets, gene prediction and expression studies. This review will focus on some biological aspects derived from $P$. brasiliensis transcriptome project which was carried out by the PbGenome Network, a consortium of 11 public and private institutions from the Midwest region of Brazil [43,44].

\section{The transcriptome project of $P$. brasiliensis - an overview}

The $\mathrm{Pb}$ Genome project aimed to identify the transcribed genes of mycelium and yeast cell-types of $P$. brasiliensis separately, being of particular interest those related to the dimorphic process, which could be key to a better comprehension of the pathobiology of this fungus. Ultimately, we sought the understanding of the cellular differentiation process at the molecular level, by means of the massive identification and annotation of genes.

The strategy employed to study the $P$. brasiliensis ( $\mathrm{Pb} 01$ isolate) transcriptome was to sequence ESTs derived from non-normalized cDNA libraries from mycelium and yeast cells cultivated at $23{ }^{\circ} \mathrm{C}$ and $36^{\circ} \mathrm{C}$, respectively (Figure). A total of 25,511 clones were sequenced corresponding to 6,022 groups which represents the repertoire of $P$. brasiliensis expressed genes [15]. This covers about 


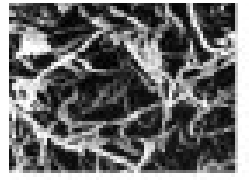

Mycelium
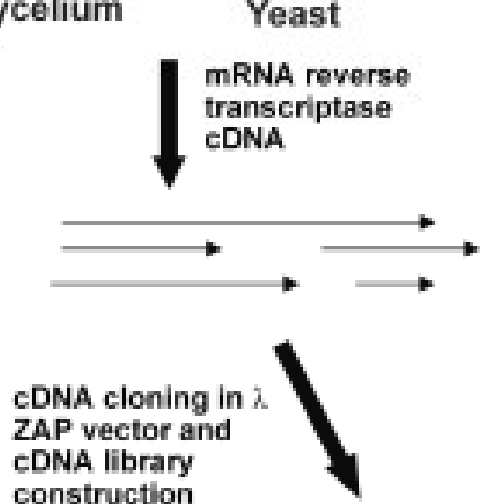
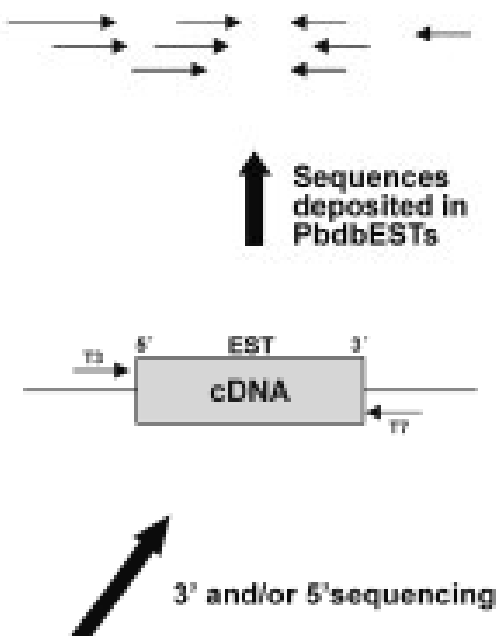

B-Galactosidase

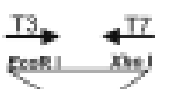

$\lambda$ ZAP Expression Vector

Figure. Strategy for EST generation employed in the $P$. brasiliensis transcriptome project. Briefly, mRNA purified from mycelium and yeast cells were used as template for cDNA synthesis and then cloned into the multiple cloning site mycelium and yeast cells were used as template for cDNA synthesis and then cloned into the multiple cloning site
(MCS) of the $\lambda$ ZAP expression vector (Stratagene). cDNA were sequenced from the $5^{\prime}$-end generating an EST (expressed sequence tags) collection which was deposited in the P. brasiliensis ESTs data bank (PbdbESTs) acces(expressed sequence tags) collection which
sed through https://www.biomol.unb.br/Pb.

$80 \%$ of the total number of predicted genes since it is estimated that $P$. brasiliensis contains $\sim 8,000$ genes. The 6,022 clusters were categorized as follows: 2,129 successfully annotated, 1,604 non-conclusively annotated and 2,289 not identified. The PbAESTs (P. brasiliensis Assembled ESTs) were classified in 18 functional COG categories: cellular metabolism (29\%), transcription $(12 \%)$, protein synthesis $(10 \%)$, energy production $(9 \%)$, control of cellular organization (4\%) and other categories.

Metabolic features. Annotation of the of P. brasi liensis transcriptome has set the grounds for a global understanding of its metabolism in both mycelia and yeast forms $[4,43]$. This fungus is able to use several carbohydrate sources including starch; and it can store reduced carbons in the form of glycogen and trehalose; these provide energy reserves that are relevant for metabolic adaptation, protection against stress and infectivity mechanisms. The glyoxylate cycle, which is also involved in pathogenicity, is present in this fungus. Classical pathways of lipid biosynthesis and degradation, including those of ketone body and sterol production, are well represented in the database of $P$. brasiliensis. It is able to synthesize de novo all nucleotides and amino acids, with the sole exception of asparagine, which was confirmed by the fungus growth in minimal medium. Sulphur metabolism, as well as the accessory synthetic pathways of vitamins and cofactors, is likely to exist in this fungus

We have identified up-regulated genes in mycelium and yeast cells encoding enzymes of central metabolic pathways (glycolysis, citrate cycle, sulphur and amino acid metabolism, alcohol fermentation and glyoxylate cycle), most of them experimentally confirmed by cDNA microarray and confirmed by Northern blot analysis [43]. The overall analysis indicates that alcohol fermentation occurs preferentially in yeast cells while mycelium saprophytic cells possess an aerobic metabolism. The putative capacity of the pathogen to also grow in anaerobiosis was evidenced by the alternative conversion of pyruvate to ethanol. Lastly, it may be able to utilize twocarbon sources in the form of acetate and ethanol through the glyoxylate cycle, since several pathways that provide substrates for the glyoxylate cycle are up-regulated in the yeast cells.

Cell cycle, DNA replication, repair and recombi nation. Data derived from transcriptome analysis revealed that cell cycle, DNA replication, DNA repair, and the recombination machineries are highly similar to that of the yeast Saccharomyces cerevisiae [87]. Among ortho$\log s$ detected in both species there are genes related to cytoskeleton structure and assembly, chromosome segregation and cell cycle control genes (CDCs). We identified at least one representative gene from each step of initiation of DNA replication.

We also identified the major players in DNA damage repair in $P$. brasiliensis, with the exception of photo-reactivation repair mechanism. Oxidative DNA damage is mainly repaired by BER (base excision repair), so this kind of repair may play an important role in host defense resistance. $P$. brasiliensis had shown a large resistance to high concentrations of $\mathrm{H}_{2} \mathrm{O}_{2}$ (Dantas, personal communication) that can induce oxidative DNA damage. So, maybe BER could be an important mechanism in the 
response of $P$. brasiliensis against oxidative stress caused by $\mathrm{H}_{2} \mathrm{O}_{2}$. In a growth-restricting environment, genetic adaptation of a microbial population involves mechanisms (e.g. error-prone polymerases) that lead to an elevated mutation rate. Evidence for the presence of mutagenic pathways in $P$. brasiliensis may account for the high variability observed in karyotypes of different isolates and the difficult to determine if $P$. brasiliensis isolates are one single species.

RNA biogenesis apparatus. The P. brasiliensis RNA biogenesis apparatus is very similar to those of other eukaryotes, such as $S$. cerevisiae [2]. PbAESTs related to almost all categories of $S$. cerevisiae RNA biogenesis were found. Two out of $12 \mathrm{~S}$. cerevisiae RNA pol II core subunits, Rbp3 and Rpb7, were found, probably reflecting the growth phase from where the cDNA libraries, used in ESTs generation, were constructed. We have also found orthologs to TBP, and at least one subunit of each TFII in $P$. brasiliensis transcriptome, except TFIIB.

With respect to the pre-mRNA processing, 65 PbAESTs orthologs to $S$. cerevisiae basal splicing machinery and 21 orthologs of 5'and 3'-ends formation processes were found. Components involved in RNA interference were detected, suggesting that this gene expression regulation mechanism is probably used by P. brasiliensis. Twelve PbAESTs related to Pol I and Pol III machineries were assigned as $S$. cerevisiae orthologs. Finally, 25 and $10 \mathrm{PbAEST}$ associated to rRNA and tRNA processing were detected. Altogether, our results enable us to depict, for the first time, a global view of transcription and RNA processing in $P$. brasiliensis.

Even though $P$. brasiliensis is classified as an ascomycete, no sexual cycle has ever been observed. However we found transcripts encoding transcription factors possibly related to sexual development such as MCM1, a MAD box protein, which interacts with cofactors that regulate mating in yeast, homologues to the mating type MAT-1 and NsdD, from Aspergillus nidulans, and a putative MAT-2 encoding sequence. In addition to the genes described above, the description of other transcription factors regulated by signal transduction pathways strongly suggest, a not yet experimentally observed, sexual cycle in P. brasiliensis.

Translation and protein fate machineries. $P$. brasiliensis translational and post-translational machineries are very similar to those of other eukaryotes, such as $S$. cerevisiae [103]. In the $P$. brasiliensis transcriptome we were able to find 78 of the 79 predicted cytosolic ribosomal proteins, corresponding to the whole small subunit and almost complete large subunit set of proteins at the exception of that encoding L23. Transcripts encoding proteins of the large subunit (L24, P1 and P2) and of the small subunit (S2, S3, S10 and S14) are highly expressed. Also, the L19 cytosolic ribosomal protein of P. brasiliensis revealed to be differentially expressed in yeast cells.

From the analysis of 27 genes related to translation initiation in S. cerevisiae, 19 orthologs were identified in the P. brasiliensis transcriptome. All eukaryotic elongation factors were detected being eEF1A one of the most expressed genes. A transcript for the putative initiation factor eIF5A was found in our analysis, which is not essential to the general protein synthesis but is essential to yeast viability. We also found eEF3 which is required for ribosome translocation in fungi and the translation termination factor eRF3, but not eRF1. Sixteen PbAESTs, showing aminoacyl-tRNA synthetases predicted activities were found in our analyses.
Of the mitochondrial ribosomal proteins, we found orthologs to $S$. cerevisiae large (20) and small (18) ribosomal subunit proteins. Although orthologs to $S$. cerevisiae mitochondrial EF-Tu, EF-G and RF1 were detected, no sequences corresponding to functional EF-Ts were identified.

As for the post-translational apparatus, 64 transcripts associated to protein modifications and 28 to protein degradation were identified. These results suggest that in $P$. brasiliensis these machineries are well conserved, when compared to other organisms.

Cell wall. Besides being the first barrier against host defences, the cell wall of human pathogenic fungus displays important antigens, thus presenting an active role during infection [64]. Cell wall is a dynamic structure, whose components are continuously modified and rearranged during fungal life cycle [83]. A striking difference in the composition of the cell wall of $P$. brasiliensis is that $\alpha$-glucan is the main yeast cell wall polysaccharide, while $\beta$-glucan and galactomannan predominate in mycelium.

Morphogenetic shift from hypha to the yeast form is essential to $P$. brasiliensis pathogenicity and cell wall $\alpha$-1,3-glucan and $\beta$-1,3-glucan seem to contribute to this process [95]. In this view, studies on the enzymes involved in cell wall biosynthesis and recycling, as well as on the cell-wall-associated molecules, should provide important information for the design of drugs that affect selectively the pathogen, and for new preventive or therapeutic approaches. The P. brasiliensis transcriptome project has revealed several data concerning the gene products that could be involved in this fungus cell wall metabolism [107].

Chitosan was not yet identified in $P$. brasiliensis cell wall; nevertheless, the gene encoding chitin deacetylase $(c d a)$, the enzyme that converts chitin to chitosan, is over expressed in the yeast phase, according to transcriptome and cDNA microarray analyses $[43,44]$. Hydrophobins are small proteins that form an amphipathic film at hydrophilic/hydrophobic interfaces covering fungal structures [114]. Two hydrophobin single-copy genes were detected in $P$. brasiliensis genome; Northern blot analysis revealed that both mRNAs are mycelium-specific and highly expressed during the onset of the mycelium-toyeast transition [1].

Although yeast cells present a higher chitin content than mycelium, the chitin synthase genes Pbrchs 1 , Pbrchs2, Pbrchs3, Pbrchs4 and Pbrchs 5 transcripts levels were higher in the former [79], suggesting an involvement of these multigenic family in morphogenesis. Our group identified a new $P$. brasiliensis chitin synthase gene (Pbrchs6) whose expression is restrict to the mycelium phase.

Genes whose products are involved in the synthesis of N-linked outer chain mannans, such as dpm1, pmt 1 , $m n n 2$ and $m n n 9$ were represented in $P$. brasiliensis transcriptome. Their transcripts were exclusive of the yeast phase, except for the mnn2 mRNA which was present in both phases.

Some transglycosidase genes (bgl2, gas 1 , crh 1 , gel1, gel2 and gel3), possibly related to the cell wall synthesis and fungal morphogenesis [10] were identified in the $P$. brasiliensis transcriptome. In this context, mycelium and yeast cells were tested for several glycohydrolases activities: high levels of $\beta$-glucanases, low amounts of $\alpha$-glucanase, chitinase and maltase were detected. $\beta-1,3-$ glucanase increasing levels correlated to the shift to the mycelial phase (unpublished data).

Taken together, these data can shed some light on the $P$. brasiliensis poorly understood cell wall metabo- 
lism, whose comprehension is essential to the development of more effective prophylactic and therapeutic procedures against this pathogen.

Hydrolytic enzymes. Saprophytic fungi display a broad spectrum of protein- and polysaccharide-hydrolysing enzymes which allow the utilization of important available nutrients. This versatility is required since in the natural environment a large diversity of substrates, including animal, vegetal and fungal sources is expected to be found. Since the mycelium form of $P$. brasiliensis is believed to be a saprobe, it should also be expected to have the enzymatic machinery necessary for the conversion of complex substrates [104]. Analysis of the P. brasiliensis transcriptome has revealed this to be true and these data was also further confirmed by enzymatic tests with the supernatants of $P$. brasiliensis cultures grown with different carbon sources [12].

The most important polysaccharides available in the natural habitats of $P$. brasiliensis are hemicellulose, cellulose, and starch which can be hydrolysed to simple sugar for fungal metabolism. Xylanases are key enzymes in the hydrolysis of hemicellulose. Although xylanase activity was detected in both fungal forms, it is six times higher in mycelium than in yeast, which is expected since hemicellulose is an abundant carbon source in the environment. P. brasiliensis also secretes cellulases confirming the transcriptome data which indicated the presence of $\beta$-1,4-glycosidase and endoglucanase homologues.

Another important plant polysaccharide is starch. As expected, amylolitic activity was detected in $P$. brasiliensis mycelium cells and an $\alpha$-amylase ortholog was found in P. brasiliensis transcriptome. Likewise, chitinolytic activity was only observed in mycelium cells. A chitinase ortholog gene that contains motifs for extracellular localization was found.

Proteases. Proteases can be classified as aspartyl proteases, cysteine proteases, metalloproteases, serine proteases and threonine proteases, depending on the nature of the active site. Many of these enzymes are of medical importance, including exogenous proteases encoded in the genomes of disease-causing organisms. A significant number (53) of protease genes were identified in the $P$. brasiliensis transcriptome database [80]. A total of 15 cDNAs, which encode energy independent protease homologs in the fungus transcriptome were annotated (3 aspartyl, 2 cysteine, 8 metallo and 2 serine proteases). Among those, 2 are exopeptidases and the remaining 13 are endopeptidases.

A gene coding an aspartyl protease of the A1 family (clan AA) is present in P. brasiliensis transcriptome. Zinc-containing metalloproteases are widely distributed in prokaryotic and eukaryotic organisms and are classified into four groups comprehending DD-carboxypeptidases, carboxypeptidases, zincins and inverzincins [70]. From the eight identified energy independent zinc metalloproteases in the $P$. brasiliensis transcriptome, four present the consensus motif HEXXH which define those proteases as members of the zincins family. Among the cysteine proteases, a caspase homolog was detected, suggesting that the programmed cell death in $P$. brasiliensis could be proteolytically regulated by this class of molecules [98]. In addition, a Kex 2 endoprotease was identified among the serine proteases. The Kex2 endoprotease presented the highest identity to the previously described kex2 gene of $P$. brasiliensis [108].

As for genes coding energy dependent proteases, 12 ESTs were detected. Among these, one corresponds to a Lon protease, a multi-functional enzyme that is conser- ved from Archaea to mammalian mitochondria, which not only degrades protein substrates but also binds DNA. Lon protease was previously described in $P$. brasiliensis [9].

The endopeptidase Clp/Hsp100 is a cytoplasmic protease that plays an important role in many cellular processes, including regulation of stress responses and protein quality control. Clp/Hsp100 proteins, such as ClpA and ClpX, associate with the ClpP protease and direct the degradation of substrate proteins bearing specific sequences. The first Clp protein described in the P. brasiliensis was the ClpB [58]. ClpB is also a heat shock protein which is induced upon the mycelium to yeast transition in $P$. brasiliensis. Other members of the Clp protease family were identified by analysis of the $P$. brasiliensis transcriptome: ClpA and ClpP2

The $26 \mathrm{~S}$ proteasome is a member of a family of 'chambered proteases' and consists of the 20S proteasome, which forms the proteolytically active core and a regulatory $19 \mathrm{~S}$ complex. The $20 \mathrm{~S}$ proteasome of higher eukaryotes is composed of seven distinct $\alpha$ and $\beta$ subunits [63]. ESTs encoding all the $\alpha$ subunits (1 to 7) and six homologues to the $20 \mathrm{~S}$ b subunit (1 to 6) are present in $P$. brasiliensis transcriptome. Of special note is the presence of the $\beta$ subunits 1,2 and 5 suggesting that the complex is proteolytically active in $P$. brasiliensis. The eukaryotic $26 \mathrm{~S}$ proteasome recognizes substrates that are tagged with a "polyubiquitin chain" - a polymer assembled from the small $(8 \mathrm{kDa})$, conserved protein ubiquitin. ESTs coding deubiquitinating enzymes are present in this transcriptome. In addition, components of the regulatory 19S complex were found in the $P$. brasiliensis transcriptome in a total of nine different subunits.

GPI-anchored proteins. Detection of glycosylphosphatidylinositol (GPI) membrane anchors in proteins of $P$. brasiliensis was described for the first time in 1995 [56]. The P. brasiliensis transcriptome analysis allowed an efficient retrieval of novel parasite GPI proteins [30]. Several studies have now established that GPI-anchored proteins represent a large class of functionally diverse proteins. They can be enzymes, surface antigens, adhesion molecules, and surface receptors [31]. GPI-anchored proteins are leading vaccine candidates, though to be of major importance for infection [39]. These proteins have certain characteristics which allow their recognition, mainly $\mathrm{N}$-terminal signal peptides and $\mathrm{C}$-terminal features that mediate GPI anchor addition at amino acid residue designated the omega $(\omega)$ site [54]; a serine-threonine rich sequence which provides sites for glycosylation; and the presence of basic or hydrophobic residues in the $\omega$-region that partially determine cellular localization $[28,111,54,55]$. By searching some of these characteristics in the translated sequences derived from $P$. brasiliensis ESTs, 20 predicted GPI-anchored proteins were identified: nine enzymes ( $\alpha$-amylase, aspartic proteinase, $\mathrm{Cu}$ and $\mathrm{Zn}$-containing superoxide dismutase 1, ECM33 and DFG5-like, $\beta$-1,3-glucanosyltransferases 1, 2 and 3, and phospholipase B); two structural proteins (Crh-like and GPI-anchored cell wall protein); one adhesion molecule (Extracellular Matrix Protein, EMP); three surface antigens (expression library immunization antigen 1, prolinerich antigen, $\beta$-1,3-glucanosyltransferase 1 ); and six hypothetical proteins. Predicted localization in plasma membrane or cell wall was reported for most of them.

Metabolism of GPI-proteins involves different processes: GPI biosynthesis, attachment of the GPI anchor to the protein carboxyl-terminus in the endoplasmic reticulum, GPI protein trafficking and sorting, and protein release by the action of phospholipases. 
In mammals, around 20 genes participate in the GPI biosynthesis pathway and are called PIG (phosphatidylinositol-glycan) genes. The glycoslyltransferase complex composed by the proteins Pig-A, Pig-C, Pig-H, GPI1, Pig-P and DPM2 (Dolichol-Phosphate-Mannose 2) catalyses the first step in the GPI synthesis [112]. Genes encoding Pig-A, Pig-C, Pig-P and DPM2 of the glycoslyltransferase complex were detected in $P$. brasiliensis transcriptome. A gene homolog to $P I G-L$, which codes an enzyme catalyzing the second step of GPI synthesis, was present in the transcriptome. In addition, $P I G-O$, which codes an enzyme involved in the EtNP transfer to the first and third mannose residues of the GIP anchor, was identified. Therefore, most of the genes involved in GPI biosynthesis were identified in P. brasiliensis, six remaining to be identified or to be described as being inexistent in this parasite.

Attachment of the GPI to a protein involves cleavage of the pre-protein at a hydrophobic aminoacid sequence, followed by the attachment of the cleaved sequence to the fully assembled GPI via a transamidase reaction. Human GPI transamidase is a protein complex, containing five homologous subunits (GPI8, PIG-S, PIG$\mathrm{T}$, and PIG-U) [57]. All of those encoding transamidases ESTs were detected in the analysis of the $P$. brasiliensis transcriptome with the exception of ESTs encoding PIG-U.

Cleavage of GIP anchor by phospholipases (PL) is a mean of selective protein release. In P. brasiliensis, a potent PLC capable of selectively hydrolyze GPI anchor was detected [56]. Two open reading frames with high sequence homology to phosphatidylinositol specific phospholipase C (PI-PLC) and phospholipase D (PLD) of Aspergillus nidulans and Aspergillus oryzae respectively, were revealed in the $P$. brasiliensis transcriptome.

Molecular chaperones. Molecular chaperones or stress proteins were first described as heat shock proteins (HSPs), since they are over-expressed in response to heat shock. Other environmental parameters, such as oxidative [72], osmolarity [99] and cold shock [59] stresses, also induce the expression of molecular chaperones. Another type of chaperone is the carbohydrate trehalose, which is produced at high levels in response to several stresses in $S$. cerevisiae and other organisms. This molecule stabilizes proteins and biological membranes, being thus considered a chemical chaperone. Its synthesis and degradation is tightly controlled in response to heat stress (for review see [110]) and it is also produced by $P$. brasiliensis, according to our transcriptome data analysis [77].

Molecular chaperones are involved in protein folding and renaturing and are also implicated in other biological processes, including the dimorphic transition of fungi and immunopathogenicity of infectious diseases. The $P$. brasiliensis HSP70 is preferentially expressed in the yeast phase [37]. Recombinant $P$. brasiliensis HSP60 was recognized by 75 serum samples of infected patients, which suggests the usefulness of HSP60 singly or in association with other recombinants antigens in the PCM diagnosis [35].

In the $P$. brasiliensis transcriptome we have identified 438 ESTs (184 in mycelium and 253 in yeast) which were clustered in 48 distinct chaperones or co-chaperones transcripts [43]. These genes were classified in families, corresponding to three small chaperones, nine HSP40s, ten HSP60s, seven HSP70s, five HSP90s, four HSP100s and ten other chaperones. Calnexin, the cytoplasmic hsp60 (cct7) and the sbal co-chaperone genes were over expressed in mycelium cells, while the co-chaperone $\operatorname{cpr} 1$, $h s p 42, h s p 60, h s p 70$ and $h s p 90$ sequences were up regulated in the yeast form. The increased expression (about $38 \%$ higher) of heat shock genes observed in the yeast phase was expected, since the differentiation of $P$. brasiliensis cells relies on a thermal shift from the environmental temperature to around $37^{\circ} \mathrm{C}$ both in vitro as in vivo. Transcriptome data greatly improved our knowledge of $P$. brasiliensis molecular chaperones, since only eight HSPs had been previously reported in this pathogen.

Transporters and insights on drug resistance. In the analysis of microbial genome, specially those pathogenic ones, the identification of transmembrane protein transporters are of special interest. This is an important class of proteins once they can play a pivotal role in microbial survival and pathogenesis, including, drug resistance. In the $P$. brasiliensis trancriptome we found 26 groups (including singlets and contigs) that show a high similarity degree with transporters proteins, 22 that probably coding for ABC (ATP Binding Cassette) transporters and four that probably code for MFS - Major Facilitator Superfamily [32]. Among ABC transporters we found, for example, Candida albicans $C D R I$ [85] and CDR 2 [97], S. cerevisae PDR5 [45] and A. nidulans $A T R F$ [3] orthologs. Regarding MSF we were also able to identify a C. albicans MDRI [23] ortholog, also pointed out as an important virulence gene. All of those genes are related in these fungi to azole resistance. These findings along with the recent reported ketoconazole resistant $P$. brasiliensis isolation from PCM patients [53] advice us to this pathogen resistance potential emergence.

Oxidative stress response. Oxidative stress is an imbalance between oxidants and antioxidants in favor of the former [100]. It can be caused by reactive oxygen species (ROS) such as the superoxide radical $\left(\mathrm{O}_{2}{ }^{\circ-}\right)$, hydrogen peroxide $\left(\mathrm{H}_{2} \mathrm{O}_{2}\right)$, hydroxyl radical $\left(\mathrm{HO}^{\circ}\right)$, and peroxynitrite $\left(\mathrm{ONOO}^{-}\right)$, a product of the reaction between superoxide with nitric oxide (NO). Enzymatic and non-enzymatic defense systems function to avoid the biological damage caused by ROS. Intracellular parasites should have antioxidants to protect against endogenously formed ROS and against ROS produced by the host cells. The enzymatic defense system present in $P$. brasiliensis include catalase, superoxide dismutase, cytochrome c peroxidase and peroxiredoxin [26].

Glutathione (GSH, $\gamma$-L-glutamyl-L-cysteinylglycine) is an abundant thiol tripeptide that takes part in the metabolism of ROS. It protects against oxidative stress by maintaining the cytosol of the cells more reduced. GSH may react with the hydroxyl radical directly, producing water [101]. Its synthesis occurs by the consecutive action of $\gamma$-glutamyl-cysteine synthetase and glutathione synthetase. Genes coding both enzymes were identified in the $P$. brasiliensis transcriptome, as well as that coding for glutathione reductase (GR), responsible for reducing oxidized glutathione (GSSG) back to GSH using NADPH as an electron donor. However, a glutathione peroxidase (GPx) gene is probably absent in the parasite's transcriptome. A substitute for this enzyme may be a 1-Cys peroxiredoxin with GPx activity [26].

Glutathione S-transferases (GST) conjugate GSH to DNA and lipid hydroperoxides, as well as mutagens, carcinogens, and other toxic chemical substances [61]. These enzymes interact with kinases and have GSHdependent peroxidase and isomerase activities [74]. $P$. brasiliensis has a GST homolog belonging to the class Omega [13] and a microsomal counterpart of this enzyme. 
The $\mathrm{Cu}^{+2}$ and $\mathrm{Fe}^{+2}$ ions play an important role in ROS production. Organisms need these them for transport, protection against oxidative stress, cell growth and development. However, these ions can catalyze hydroxyl radical formation by the Fenton reaction: $\mathrm{Fe}^{+2}+\mathrm{H}_{2} \mathrm{O}_{2}+\mathrm{H}^{+}$ $\rightarrow \mathrm{Fe}^{+3}+\mathrm{H}_{2} \mathrm{O}+\mathrm{HO}^{\bullet}$ [51]. Therefore, the cellular levels of $\mathrm{Fe}^{+2}$ and $\mathrm{Cu}^{+2}$ should be carefully controlled. Noteworthy is the presence of a frataxin gene homolog in P. brasiliensis. In $S$. cerevisiae, frataxin functions both as a chaperone for $\mathrm{Fe}^{2+}$ when mitochondrial iron is limiting, and as a storage molecule for $\mathrm{Fe}^{3+}$ when iron is in excess [81]. In humans, defects in frataxin causes Friedreich ataxia (FRDA), a severe neuro- and cardio-degenerative disease in humans, in which mitochondria are unable to handle iron properly $[62,91]$. Studies on $P$. brasiliensis frataxin may help to clarify the function of this protein in humans.

The transcripton factors Yap1 and Skn7 function in signaling pathways used by fungal cells to control the expression of genes involved in the oxidative-stress response [76]. The presence of ESTs coding both factors in $P$. brasiliensis is important to preserve cellular viability when ROS are produced endogenously or as a result of host immune attack.

Virulence. The search for PbAESTs related to virulence genes was based on those orthologs that fitted molecular Koch's postulate: Falkow's postulate [29,41] and made possible the annotation of 28 virulence PbAESts $[43,105]$. Among those groups are metabolism gene orthologs (eight different groups), two PbAESTs that probably code for ICL (isocitrate lyase) and MLS1 (malate synthase) $C$. albicans glyoxylate cycle orthologs, that is upregulated in $P$. brasiliensis yeast form [43]. This phenomenon was also described for $C$. albicans during its intracellular phase [65], where it is thought to play a crucial function in nutritional furnish. A similar mechanism can be postulated for P. brasiliensis into the macrophage, after phagocytosis. Those genes related to cell wall biosynthesis and stabilization is also reported as critical to pathogenesis. We were able to find six PbAESts that shares high similarity degree with fungal cell wall biosynthesis that were previously reported as important virulence genes $[21,22,69,106]$. The disruption of these genes affects C. albicans survival and attenuates its virulence, so these can be potential drug targets, also because cell wall is the key difference between fungal and human cell. During the infection, $P$. brasiliensis is submitted to oxidative stresses caused by reactive oxygen (ROI) and nitrogen (RNI) intermediates generated during immune response to infection. In our transcriptome we found at least four groups that probably codes for enzymes that are able to ROI and RNI detoxification, whose other fungi orthologs also fit Falkow's postulate, decreasing their virulence when disrupted, and reversing this phenotype when the null mutants were supplied with the disrupted gene. The other ten $\mathrm{PbAests}$ assigned as potential virulence genes have miscellaneous fungi orthologs [43], as for example: phospholipase, urease, multi drug resistance transporter, signal transduction genes and other diverse functions.

\section{Perspectives}

Functional analysis of the genes described in the $P$. brasiliensis transcriptome will yield relevant information about cellular differentiation, pathogenicity and/or virulence as genetic tools become available for this pathogen. However, functional analysis by gene disruption in $P$. brasiliensis is hampered by the evidence that isolates have different number of chromosomes [42] and cells are normally multinucleated.

Peptide analogues to human proteins have been reported as potent anti-fungal agents [48]. The high potency and low toxicity make these peptides strong candidates for the treatment of several mycoses. These diseases are traditionally treated with amphotericin B and azoles (fluconazole or itraconazole, among others) but these drugs are becoming less effective as drug resistance arise among several pathogenic fungi. However, therapeutic peptides are less likely to induce drug resistance; for example, peptides derived from MSH (melanocite stimulating hormone) have shown no toxicity in pre-clinical and in vitro studies [48].

Among the perspectives that we foresee as a consequence of the transcriptome project we would like to highlight the following:

1) In vivo expression analysis will be extended to the genes proposed to be involved in host-pathogen interaction, including the differentially expressed genes in mycelium and yeast cells, heat shock, essential genes, putative drug targets and virulence factors. cDNA microarray experiments are currently being carried out in order to evaluate the in vivo expression profile of these genes in macrophages and human pulmonary epithelial cells infected by $P$. brasiliensis.

2) S. cerevisiae can be used as a tester model for gene functional analysis by trans-complementation as recently demonstrated [78].

3) RNA interference (RNAi), a natural process which relies in the ability of the cell to target and destroy foreign genetic material, may represent an attractive alternative for gene analysis in P. brasiliensis. This approach has been successfully used in other fungi such as $H$. capsulatum, Cryptococcus neoformans and Neurospora crassa [38]. The identification of five $N$. crassa orthologs (rrp-3, qde-2, sms-2, dcl-2 and rec $Q-2)$ in the $P$. brasiliensis transcriptome is an evidence that RNAi may also occur in this fungus thus encouraging the development of an efficient strategy for functional gene analysis.

4) In silico design of synthetic peptides based on ESTs sequences may generate new antifungal molecules for the treatment of PCM. 


\section{References}

1. Albuquerque $P$, Kyaw $C M$, Saldanha RR, Brigido MM, Felipe MSS, Silva-Pereira I. Pbhyd1 and Pbhyd2: two mycelium specific hydrophobin genes from the dimorphic fungus Paracoccidioides brasiliensis. Fungal Genet Biol 2004; 41: 510-520.

2. Albuquerque $P$, Baptista $A J$ Derengowsky LS, Procópio L, Nicola AM Arraes FBM, Souza DP, Kyaw CM, SilvaPereira I. Paracoccidioides brasiliensis RNA biogenesis apparatus revealed by functional genome analysis. Genet Mol Res, in press.

3. Andrade AC, Van Nistelrooy JGM, Peery $\mathrm{RB}$, Skatrud PL, De Waard MA. The role of $\mathrm{ABC}$ transporters from Aspergillus nidulans in protection against cytotoxic agents and in antibiotic production. Mo Gen Genet 2000; 263: 966-977.

4. Arraes FBM, Benoliel B, Burtet RT, Costa PLN, Galdino AS, Lima LHA, MarinhoSilva C, Oliveira-Pereira L, Pfrimer P. Procópio-Silva L, Reis VCB, Felipe MSS. General metabolism of the dimorphic and pathogenic fungus Paracoccidioides brasiliensis. Genet Mol Res, in press.

5. Arruda C, Franco MF, Kashino SS, Nascimento FR, Fazioli A, Vaz CA Russo M, Calich VL. Interleukin-12 protects mice against disseminated infection caused by Paracoccidioides brasiliensis but enhances pulmonary inflammation. but enhances pulmonary inflammation
Clin Immunol 2002; 103: 185-195.

6. Bagagli E, Sano A, Coelho KI, Alquati S, Miyaji M, Camargo ZP, Gomes GM, Franco $M$, Montenegro MR Isolation of Paracoccidioides brasiliensis from armadillos (Dasypus noveminctus) captured in an endemic area of Paracoccidioidomycosis. Am J Trop Med Hyg 1998; 58: 505-512.

7. Bailek R, lbricevic A, Fothergill A, Begerow D. Small subunit ribosomal DNA sequence shows Paracoccidioides brasiliensis closely related to Blastomyces dermatitidis. J Clin Microbio 2000; 38: 3190-3193.

8. Barbosa MS, Passos Cunha DA, Felipe MSS, Jesuíno RSA, Pereira M, Soares CMA. The glyceraldehyde-3-phosphate dehydrogenase homologue is differentially regulated in phases of

Paracoccidioides brasiliensis: molecular and phylogenetic analysis. Fungal Genet Biol 2004; 41: 667-675.

9. Barros TF, Puccia R. Cloning and Characterization of a LON gene homologue from the human pathogen Paracoccidioides brasiliensis. Yeast 2001; 18: 981-988.

10. Beauvais A, Latgé JP. Membrane and cell wall targets in Aspergillus fumigatus. Drug Resist Update 2001; 4: 38-49.

11. Benard G, Romano CC, Cacere CR, Juvenale M, Mendes-Giannini MJ, Duarte AJ. Imbalance of IL-2, IFN-gamma and IL-10 secretion in the immunosuppression associated with human paracoccidioidomycosis. Cytokine 2001; 13: 248-252.

12. Benoliel, B, Arraes FBM, Reis, VCB, Siqueira SJL, Parachin, NS, Torres, FAG. Hydrolytic Enzymes in Paracoccidioides brasiliensis - ecological aspects. Genet Mol Res, in press.

13. Board PG, Coggan M, Chelvanayagam G, Easteal. S, Jermiin LS, Schulte GK, Danley DE, Hoth LR, Griffor MC, Kamath AV, Rosner MH, Chrunyk BA, Perregaux DE, Gabel CA, Geoghegan KF, Pandit J. Identification, characterization, and crystal structure of the Omega class glutathione transferases. J Biol Chem 2000; 275: 24798-24806.

14. Borba CM, Schäffer GMV Paracoccidioides brasiliensis: virulence and an attempt to induce the dimorphic process with fetal calf serum. Mycoses 2002; 45: 174-179.
15. Brígido MM, Walter MEMT, Oliveira AG Inoue MK, Anjos DS, Sandes EFO Gondim JJ, Carvalho MJA, Almeida Jr NF, Felipe MSS. Bioinformatics of the Paracoccidioides brasiliensis EST
Project. Genet Mol Res, in press.

16. Brummer E, Castaneda E, Restrepo A. Paracoccidioidomycosis: an update. Clin Microbiol Rev 1993; 6: 89-117.

17. Brummer E, Hanson LH, Stevens DA. Gamma-interferon activation of macrophages for killing of Paracoccidioides brasiliensis and evidence for nonoxidative mechanisms. Int J Immunopharmacol 1988; 10: 945-52.

18. Brummer E, Hanson LH, Restrepo A Stevens DA. In vivo and in vitro activation of pulmonary macrophages by IFNgamma for enhanced killing of Paracoccidioides brasiliensis or Blastomyces dermatitidis. J Immunol 1988; 140: 2786-2789.

19. Brummer E, Hanson LH, Restrepo A Stevens DA. Intracellular multiplication of Paracoccidioides brasiliensis in macrophages: killing and restriction of multiplication by activated macrophages. Infect Immun 1989; 57: 2289-2294.

20. Brummer E, Sun SH, Harrison JL, Perlman AM, Philpott DE, Stevens DA. Ultrastructure of phagocytosed Paracoccidioides brasiliensis in nonactivated or activated macrophages. Infect Immun 1990; 58: 2628-2636.

21. Bulawa CE, Miller DW, Henry LK, Becker $\mathrm{JM}$. Attenuated virulence of chitin-deficient mutants of Candida albicans. Proc Natl Acad Sci. USA 1995; 92: 1057010574

22. Buurman ET, Westwater C, Hube B, Brown AP, Odds FC, Gow NAR. Molecular analysis of CaMnt1p, a mannosyl-transferase important for adhesion nosyl-transferase important for adhesion Natl Acad Sci USA 1998; 95: 7670-7675.

23. Calabrese D, Bille J, Sanglard D. A novel multidrug efflux transporter gene of the major facilitator superfamily from Candida albicans (FLU1) conferring resistance to fluconazole. Microbiology 2000; 146: 2743-2754.

24. Calich VL, Kashino SS. Cytokines produced by susceptible and resistant mice in the course of Paracoccidioides brasiliensis infection. Braz J Med Biol Res 1998; 31: 615-623.

25. Camargo ZP, Taborda CP. Antigenic relationship between Paracoccidioides brasiliensis isolated from faeces of a penguin and a human isolate of $P$. brasiliensis. J Med Vet Mycol 1993; 31: 347-352.

26. Campos EG, Jesuíno RSA Dantas AS, Brígido MM, Felipe MSS. Oxidative stress response in Paracoccidioides brasiliensis. Genet Mol Res, in press.

27. Cano LE, Kashino SS, Arruda C, André $\mathrm{D}$, Xidieh CF, Singer-Vermes LM, Vaz CA, Burger E, Calich VL. Protective role of gamma interferon in experimental pulmonary paracoccidioidomycosis. Infect monary paracoccidioidomy

28. Caro LH, Tettelin H, Vossen JH, Ram $\mathrm{AF}$, van den Ende $\mathrm{H}$, Klis FM. In silicio identification of glycosy-phosphatidylinositol-anchored plasma-membrane and cell wall proteins of Saccharomyces cerevisiae. Yeast 1997; 13: 1477-1489.

29. Casadevall A, Pirofski L. Host-pathogen interactions: the attributes of virulence. $J$ Infect Dis 2001; 18:, 337-344.

30. Castro NS, Maia ZA, Pereira M, Soares CMA. Screening for glycosylphosphatidylinositol (GPI)-anchored proteins in Paracoccidioides brasiliensis transcriptome. Genet Mol Res, in press.
31. Chatterjee S, Mayor S. The GPI-anchor and protein sorting. Cell Mol Life Sci 2001; 58: 1969-1987.

32. Costa CS, Albuquerque FC, Andrade RV, Oliveira GC, Almeida MF, Brigido MM, Maranhão AQ. Transporters in the Paracoccidioides brasiliensis transcriptome: insights on drug resistance. Genet Mol Res, in press.

33. Coutinho ZF, Silva D, Lazera M, Petri V, Oliveira RM, Sabroza PC, Wanke B. Paracoccidioidomycosis mortality in Brazil (1980-1995). Cad Saude Publica 2002; 18: 1441-1454.

34. Cunha AF, Sousa MV, Silva SP, Jesuíno RSA, Soares CMA., Felipe MSS. Identification, $\mathrm{N}$-terminal region sequencing and similarity analysis of differentially expressed proteins in

Paracoccidioides brasiliensis. Med Mycol 1999; 37: 115-121.

35. Cunha DA, Zancopé-Oliveira RM, Felipe MSS, Salem-Izacc SM, Deepe Jr GS, Soares, CMA. Heterologous expression, purification and immunological reactivity of a recombinant HSP60 from Paracoccidioides brasiliensis. Clin Diagn Lab Immunol 2002; 9: 374-377.

36. da Silva SP, Felipe MSS, Pereira M, Azevedo MO, Soares CMA. Phase transition and stage-specific protein synthesis in the dimorphic fungus Paracoccidioides brasiliensis. Exp Mycol 1994; 18: 294299.

37. da Silva SP, Borges-Walmsley MI, Pereira IS, Soares CMA, Walmsley AR, Felipe MSS. Differential expression of an hsp 70 gene during transition from the mycelial to the infective yeast form of the human pathogenic fungus Paracoccidioides brasiliensis. Mo Microbiol 1999; 31: 1039-1050.

38. de Backer MD, Raponi M, Arndt GM RNA-mediated gene silencing in non-pathogenic and pathogenic fungi. Curr Opin Microbiol 2002; 5: 323-329.

39. Delgado N, Xue J, Yu JJ, Hung CY, Cole GT. A recombinant beta-1,3-glucanosyltransferase homolog of Coccidioides posadasii protects mice against coccidioiposadasil protects mice against coccidioidomycosi.

40. Dixon DM, Casadevall A, Klein B, Mendonza L, Travassos LR, Deepe Jr GS. Development of vaccines and their use in the prevention of fungal infection. Med Mycol 1998; 36: 57-67.

41. Falkow S. Molecular Koch's postulates applied to bacterial pathogenicity - a personal recollection 15 years later. Nature Rev Microbiol 2004; 2: 67-72.

42. Feitosa LS, Cisalpino PS, dos Santos MR, Mortara RA, Barros TF, Morais FV,
Puccia R, da Silveira JF, de Camargo ZP. Chromosomal polymorphism, synteZP. Chromosomal polymorphism, syntenic relationships and ploidy in th
genic fungus Paracoccidioides genic fungus Paracoccidioides 60-69.

43. Felipe MSS, Andrade RV, Arraes FBM Nicola AM , Maranhão AQ, Torres FAG Silva-Pereira I, Poças-Fonseca MJ, Campos EG, Moraes LMP, Andrade PA Campos EG, Moraes LMP, Andrade PA,
Tavares AHFP, Silva SS, Kyaw CM, Tavares AHFP, Silva SS, Kyaw CM,
Souza, DP, PbGenome Network, Pereira $M$, Jesuíno RSA, Andrade EV, Parente JA, Oliveira GS, Barbosa MS, Martins NF, Fachin AL, Cardoso RS, Passos GAS, Almeida NF, Walter MEMT, Soares CMA, Carvalho MJA, Brígido MM. Transcriptional profiles of the human pathogenic fungus Paracoccidioides brasiliensis in mycelium and yeast cells. J Biol Chem 2005, in press

44. Felipe MSS, Andrade RV, Petrofeza SS, Maranhão AQ, Torres FAG, Albuquerque $\mathrm{P}$, Arraes FB, Arruda M, Azevedo MO, 
Baptista AJ, Bataus LAM, Borges CL, Campos EG, Cruz MR, Daher BS Dantas A, Ferreira MA, Ghil GV, Jesuíno RS, Kyaw CM, Leitão L, Martins CR, Moraes LMP, Neves EO, Nicola AM, Alves ES, Parente JA, Pereira M, PocasFonseca MJ, Resende R, Ribeiro BM Saldanha RR, Santos SC, Silva-Pereira I, Silva MA, Silveira E, Simões IC, Soares RB, Souza DP, De-Souza MT, Andrade EV, Xavier MA, Veiga HP, Venâncio EJ, Carvalho MJ, Oliveira AG, Inoue MK, Almeida NF, Walter ME, Soares CMA Brigido MM. Transcriptome characterization of the dimorphic and pathogenic fungus Paracoccidioides brasiliensis by EST gus Paracoccidioides brasiliensis by
analysis. Yeast 2003; 20: 263-271.

45. Ferreira-Pereira A, Marco S, Decottignies A, Nader J, Goffeau A, Rigaud JL. Threedimensional reconstruction of the Saccharomyces cerevisiae multidrug resistance protein Pdr5p. J Biol Chem resistance protein Pdr5p.

46. Fonseca CA, Jesuíno RSA, Felipe MSS Cunha DA, Brito WA, Soares CMA. Twodimensional electrophoresis and characterization of antigens from Paracoccidioides brasiliensis. Microbes Infect 2001; 3: 535-542.

47. Fornari MC, Bava AJ, Guereno MT, Berardi VE, Silaf MR, Negroni R, Diez RA. High serum interleukin- 10 and tumor necrosis factor alpha levels in chronic paracoccidioidomycosis. Clin Diagn Lab Immunol 2001; 8: 1036-1038.

48. Foubister V. Superpeptide to trea Candida albicans. Drug Discov Today 2003; 8: 380-381.

49. Franco M, Peracoli MT, Soares A Montenegro R, Mendes RP, Meira DA. Host-parasite relationship in paracoccidioidomycosis. Curr Top Med Myco 5: $115-149$

50. Gonzalez A, de Gregori W, Vélez D, Restrepo A, Cano LE. Nitric oxide participation in the fungicidal mechanism of gamma interferon-activated murine macrophages against Paracoccidioides brasiliensis conidia. Infect Immun 2000; 68: 2546-2552.

51. Gutteridge JM. Antioxidant properties of caeruloplasmin towards iron- and copperdependent oxygen radical formation. FEBS Lett 1983; 157: 37-40.

52. Hahn RC, Font's CJ, Batista RD, Hamdan JS. In vitro comparison of activities of terbinafine and itraconazole against Paracoccidioides brasiliensis. J Clin Microbiol 2002; 40: 2828-2831.

53. Hahn RC, Morato Conceição YT, Santos $\mathrm{NL}$, Ferreira JF, Hamdan JS. Disseminated paracoccidioidomycosis: correlation between clinical and in vitro resistance to ketoconazole and trimethoprim sulphamethoxazole. Mycoses 2003; 46: 342-347.

54. Hamada, K, Terashima H, Arisawa M, Kitada K. Amino acid sequence requirement for efficient incorporation of glycosylphosphatidylinositol-associated proteins into the cell wall of Saccharomyces cerevisiae. J Biol Chem 1998; 273: 26946-26953.

55. Hamada K, Terashima $\mathrm{H}$, Arisawa $\mathrm{M}$, Yabuki N, Kitada K. Amino acid residues in the omega-minus region participate in cellular localization of yeast glycosylphosphatidylinositol-attached proteins. J Bacteriol 1999; 181: 3886-3889.

56. Heise N, Travassos LR, de Almeida ML. Paracoccidioides brasiliensis expresses both glycosylphosphatidylinositol-anchored proteins and a potent phospholipase C. Exp Mycol 1995; 19: 111-119.

57. Hong Y, Ohishi K, Kang JY, Tanaka S, Inoue $N$, Nishimura J, Maeda $Y$, Kinoshita T. Human PIG-U and yeast Cdc91p are the fifth subunit of GPI tran- samidase that attaches GPI-anchors to proteins. Mol Biol Cell 2003; 14: 1780 1789.

58. Jesuíno RSA, Azevedo MO, Felipe MSS, Pereira M, Soares CMA. Characterization of a chaperone ClpB homologue of Paracoccidioides brasiliensis. Yeast 2002; 19: 963-972.

59. Kandror O, Bretschneider N, Kreydin E, Cavalieri D, Goldberg AL. Yeast adapt to near-freezing temperatures by STRE/Msn2,4-dependent induction of trehalose synthesis and certain molecular chaperones. Mol Cell 2004; 13: 771-781.

60. Kashino SS, Fazioli RA, Cafalli-Favati C, Meloni-Bruneri LH, Vaz CA, Burger E, Singer LM, Calich VL. Resistance to Paracoccidioides brasiliensis infection is linked to a preferential Th1 immune response, whereas susceptibility is associated with absence of IFN-gamma production. J Interferon Cytokine Res 2000; 20: 89-97.

61. Ketterer B, Meyer DJ. Glutathione transferases: a possible role in the detoxication and repair of DNA and lipid hydroperoxides. Mutat Res 1989; 214:3340.

62. Koutnikova H, Campuzano V, Foury F Dolle P, Cazzalini O, Koenig M. Studies of human, mouse and yeast homologues indicate a mitochondrial function for frataxin. Nat Genet 1997; 16: 345-351.

63. Krüger E, Kloetzel PM, Enenkel C. $20 \mathrm{~S}$ proteasome biogenesis. Biochimie 2001; 83: 289-293

64. Latgé JP. Aspergillus fumigatus and aspergillosis. Clin Microbiol Rev 1999; 12: 310-350.

65. Lorenz MC, Fink GR. The glyoxylate cycle is required for fungal virulence. Nature 2001; 412: 83-86

66. Marques Mello L, Silva-Vergara ML, Rodrigues VJr. Patients with active infection with Paracoccidioides brasiliensis present a Th2 immune response characterized by high Interleukin- 4 and Interleukin-5 production. Hum Immunol Interleukin-5 productic

67. McEwen JG, Bedoya V, Patino MM Salazar ME, Restrepo AE. Experimental murine paracoccidioidomycosis induced by the inhalation of conidia. J Med Vet Mycol 1987; 25: 165-175.

68. McEwen JG, Garcia AM, Ortiz BL, Botero $S$, Restrepo $A$. In search of the natural habitat of Paracoccidioides brasiliensis. Arch Med Res 1995; 26: 305-306.

69. Mio T, Kokado M, Arisawa M; YamadaOkabe H. Reduced virulence of Candida albicans mutants lacking the GNA1 gene encoding glucosamine-6-phosphate acetyltransferase. Microbiology 2000 146: 1753-1758.

70. Miyoshi S, Shinoda S. Microbial metallo proteases and pathogenesis. Microbes proteases and pathogen
Infect 2000; 2: 91-98.

71. Montoya AE, Moreno MN, Restrepo A McEwen JG. Electrophoretic karyotype of clinical isolates of Paracoccidioides brasiliensis. Fungal Genet Biol 1997; 21: 223 227.

72. Moraitis C, Curran BP. Reactive oxygen species may influence the heat shock response and stress tolerance in the yeast Saccharomyces cerevisiae. Yeast 2004; 21: 313-323.

73. Moreira SFI, Bailão AM, Barbosa MS Jesuíno RSA, Felipe MSS, Pereira M, Soares CMA. Monofunctional catalase P of Paracoccidioides brasiliensis: identification, characterization, molecular cloning and expression analysis. Yeas 2004; 30: 173-182.

74. Morel F, Rauch C, Petit E, Piton A, Theret N, Coles B, Guillouzo A. Gene and protein characterization of the human glutathione S-transferase kappa and evidence for a peroxisomal localization. J Biol Chem 2004; 279: 16246 162453.

75. Moscardi-Bacchi M, Brummer E, Stevens DA. Support of Paracoccidioides brasiliensis multiplication by human monocytes or macrophages: inhibition by tes or macrophages: inhibition by 1994; 40: 159-64.

76. Moye-Rowley WS. Regulation of the transcriptional response to oxidative stress in fungi: similarities and differences. Eukaryot Cell 2003; 2: 381-389.

77. Nicola AM, Andrade RV, Silva-Pereira, I. Molecular chaperones in the Paracoccidioides brasiliensis transcriptome. Genet Mol Res, in press.

78. Niño-Vega GA, Sorais F, Calcagno AM, Ruiz-Herrera J, Martinez-Espinoza AD, San-Blas G. Cloning and expression analysis of the ornithine decarboxylase gene (PbrODC) of the pathogenic fungus 21: 211-218.

79. Niño-Vega GA, Munro CA, San-Blas G, Gooday GW, Gow NAR. Differential expression of chitin synthase genes during temperature-induced dimorphic transition in Paracoccidioides brasiliensis. Med Mycol 2000; 38: 31-39.

80. Parente JA, Costa M, Pereira M, Soares CMA. Transcriptome overview of Paracoccidioides brasiliensis proteases. Genet Mol Res, in press.

81. Park S, Gakh O, O'Neill HA, Mangravita A, Nichol H, Ferreira GC, Isaya G. Yeas frataxin sequentially chaperones and stores iron by coupling protein assembly with iron oxidation. J Biol Chem 2003; 278: 31340-31351.

82. Pereira LA, Pereira M, Felipe MSS, Zancopé-Oliveira R, Soares CMA Proteomic identification, nucleotide sequence, heterologous expression and immunological reactivity of the triosephosphate isomerase of Paracoccidioides brasiliensis. Microbes Infect 2004; 6: 892 900.

83. Popolo L, Gualtieri T, Ragni E. The yeast cell-wall salvage pathway. Med Mycol 2001; 39: 111-121.

84. Prade RA, Ayoubi P, Krishnan S, Macwana S, Russell H. Accumulation of stress and inducer-dependent plant-cellwalldegrading enzymes during asexual wallegrading enzymes during asexual Genetics 2001; 157: 957-967.

85. Prasad R, De Wergifosse P, Goffeau A, Balzi E. Molecular cloning and characterization of a novel gene of Candida albicans, CDR1, conferring multiple resistance to drugs and antifungals. Curr Genet 1995; 27: 320-29.

86. Reinoso C, Niño-Vega G, San-Blas G, Dominguez $A$. The genome of Paracoccidioides brasiliensis: an overview. IV Congresso Virtual de Micologia de Hongos patógenos em América Latina, 2003.

87. Reis VCB, Torres FAG, Poças-Fonseca MJ, De-Souza MT, Souza DP, Almeida JRM, Marinho-Silva C, Parachin NS, Dantas AS, Mello-de-Sousa TM, Moraes LMP. Cell cycle, DNA replication, repair and recombination in the dimorphic human pathogenic fungus Paracoccidioides brasiliensis. Genet Mo Res, in press.

88. Restrepo A, McEwen JG, Castaneda E. The habitat of Paracoccidioides brasiliensis: how far from solving the riddle? Med Mycol 2001; 39:233-241.

89. Restrepo AM. The ecology of Paracoccidioides brasiliensis: a puzzle still unsolved. J Med Vet Mycol 1985; 23:323-334. 
90. Rodrigues G, Travassos LR. Nature of the reactive epitopes in $P$. brasiliensis polysaccharide antigen. Med Mycol 1994; 32: 77-81.

91. Rotig A, de Lonlay P, Chretien D, Foury F, Koenig M, Sidi D, Munnich A, Rustin $P$. Aconitase and mitochondrial iron-sulphur protein deficiency in Friedreich ataxia. Nat Genet 1997; 17: 215-217.

92. Salem-Izacc SM, Gómez FJ, Jesuino RSA, Fonseca CA, Felipe MSS, Deepe JrG.S, Soares CMA. Molecular cloning, characterization and expression of th heat shock protein 60 gene from the human pathogenic fungus Paracoccidioides brasiliensis. Med Mycol 2001; 39: 445-455

93. Salem-Izacc SM, Jesuíno RSA, Brito WA, Pereira M, Felipe MSS, Soares CMA. Protein synthesis patterns of Paracoccidioides brasiliensis isolates in stage-specific forms and during cellular differentiation. J Med Vet Mycol 1997; 35 : 205-211.

94. San Blas G. Paracoccidioidomycosis and its etiologic agent Paracoccidioides brasiliensis. J Med Vet Mycology 1993; 31: 99-113.

95. San Blas G, San Blas F. Biochemistry of Paracoccidioides brasiliensis dimorphism. In: Franco M, Lacaz C, RestrepoMoreno A, Del Negro A (Eds.) Paracoccidioidomycosis. Boca Raton, Florida, CRC Press: 1994; 49-66.

96. San-Blas G, Niño-Vega G, Iturriaga $T$. Paracoccidioides brasiliensis and paracoccidioidomycosis: molecular approaches to morphogenesis, diagnosis, epidemiology, taxonomy and genetics. Med Mycol 2002; 40: 225-242.

97. Sanglard D, Ischer F, Monod M, Bille J. Cloning of Candida albicans genes conferring reistance to azole antifungal agents: characterization of CDR2, a new multidug $A B C$ transporter gene. Microbiology 1997; 143: 405-16.

98. Shi Y. Mechanisms of caspase activation and inhibition during apoptosis. Mol Cell 2002; 9: 459-470.
99. Siderius M, Rots E, Mager WH. Highosmolarity signalling in Saccharomyces cerevisiae is modulated in a carbon-source-dependent fashion. Microbiology 1997; 143: 3241-3250.

100. Sies H. Oxidative stress: oxidants and antioxidants. Exp Physiol 1997; 82: 291 295

101. Sigler K, Chaloupka J, Brozmanova J Stadler N, Hofer M. Oxidative stress in microorganisms-I. Microbial vs. higher cells - damage and defenses in relation to cell aging and death. Folia Microbiol (Praha) 1999; 44: 587-624.

102. Souto JT, Figueiredo F, Furlanetto A, Pfeffer K, Rossi MA, Silva JS. Interferongamma and tumor necrosis factor-alpha determine resistance to Paracoccidioides brasiliensis infection in mice. Am J Pathol 2000; 156: 1811-1820.

103. Souza DP, Silva SS, Baptista AJ, Nicola AM, Kyaw CM, Silva-Pereira I. Paracoccidioides brasiliensis translation and protein fate machineries revealed by functional genome analysis. Genet Mol Res, in press.

104.St Leger RJ, Joshi L, Roberts DW Adaptation of proteases and carbohydrates of saprophytic, phytopathogenic and entomopathogenic fungi to the requirements of their ecological niches. Microbiology 1997; 143: 1983-1992.

105. Tavares AH, Silva SS, Bernardes VV, Maranhão AQ, Kyaw CM, PoçasFonseca MJ, Silva-Pereira I. Virulence insights from the Paracoccidioides brasiliensis transcriptome. Genet Mol Res, in press.

106. Timpel C, Strahl-Bolsinger S Ziegelbauer K, Ernst JF. Multiple functions of Pmt1p-mediated protein O-mannosylation in the fungal pathogen Candida albicans. J Biol Chem 1998; 273: 20837-20846

107. Tomazett PK, Cruz AHS, Bonfim SMRC Soares CMA, Pereira M. The cell wall of Paracoccidioides brasiliensis: Insights from its transcriptome. Genet Mol Res, in press.
108. Venancio EJ, Daher BS, Andrade RV, Pereira M, Soares CMA, Felipe MSS. The Kex2 gene from the dimorphic and human pathogenic fungus Paracoccidioides brasiliensis. Yeast 2002; 19: 1221-1231.

109. Venâncio EJ, Kyaw CM, Mello CV, Silva SP, Soares CMA, Felipe MSS. Identification of differentially expressed transcritps in the human pathogenic fungus Paracoccidioides brasiliensis by differential display. Med Mycol 2002; 40: 45-51.

110. Voit EO. Biochemical and genomic regulation of the trehalose cycle in yeast: review of observations and canonical model analysis. J Theor Biol 2003; 223: 55-78.

111. Vossen JH, Muller WH, Lipke PN, Klis FM. Restrictive glycosylphosphatidylinositol anchor synthesis in cwh6/gpi3 yeast cells causes aberrant biogenesis of cell cells causes aberrant biogenesis of cell 2202-2209.

112. Watanabe R, Murakami Y, Marmor MD, Inoue N, Maeda Y, Hino J, Kangawa K, Julius M, Kinoshita T. Initial enzyme for glycosylphosphatidylinositol biosynthesis requires PIG-P and is regulated by DPM2. EMBO J 2000; 19: 4402-4411.

113. Woods JP. Knocking on the right door and making a comfortable home: Histoplasma capsulatum intracellular pathogenesis. Curr Opin Microbiol 2003; 6 : 327-331.

114. Wösten HA, de Vocht ML. Hydrophobins, the fungal coat unravelled. Biochim Biophys Acta 2000; 1469: 79-86. 